\title{
KEBIJAKAN TATA RUANG DALAM PENERAPAN PUSAT KEGIATAN LOKAL DI KABUPATEN KUNINGAN UNTUK PENINGKATAN PENDAPATAN ASLI DAERAH
}

\author{
Oleh : \\ Haris Budiman \\ Fakultas Hukum Universitas Kuningan \\ Email: harisbudiman9@yahoo.co.id
}

\begin{abstract}
Determining Cilimus as Local Activities Center is hoped that it can support Kuningan Regency as Conservative Regency and improve societies' prosperity through improving Regional Native Income. In fact, policy implementation isn't guided by printing layout that has been stated so there are some violations of a function. The formulation of problems in this thesis are how the implementation of local activities center in Cilimus Sub district to improve regional native income is and is there a violation of a function on the policy implementation in Cilimus Sub district. The objectives of this research are to analyze the implementation of local activities center in Cilimus Sub district and to analyze whether or not there is a violation of a function on the policy implementation in Cilimus Sub district. The method of this research is non-doctrinal with socio-legal approach because it discusses law in social perspective. In the level of policy implementation about the use of field function, there is a violation of agriculture field usage to be housing. Regional government's policy to improve regional native income doesn't pay attention on printing layout planning that has been stated. The change of agriculture field function is a threat in achieving stability of food, deciding that Kuningan Regency is a main agriculture product producer. The implication of the change function has juridical consequences administratively, penal law or civil law. But the effort to enforce the law isn't done optimally so the violation is still running.
\end{abstract}

Keywords : Policy, Local Activities Center, Regional Native Income 


\begin{abstract}
Abstrak
Penetapan Cilimus sebagai Pusat Kegiatan Lokal diharapkan dapat mendukung Kabupaten Kuningan sebagai Kabupaten Konservasi, juga untuk meningkatkan kesejahteraan masyarakat. Akan tetapi pada tataran implementasi kebijakan yang dibuat tidak berpedoman pada rencana tata ruang yang telah ditetapkan sehingga terjadi pelanggaran alih fungsi peruntukan. Rumusan masalah yang dikaji bagaimanakah penerapan Pusat Kegiatan Lokal Di Kecamatan Cilimus untuk meningkatkan Pendapatan Asli Daerah?dan benarkah telah terjadi inkonsistensi kebijakan alihfungsi peruntukan kawasan dalam pelaksanaan kebijakan Pusat Kegiatan Lokal di Kecamatan Cilimus? Tujuannya untuk menganalisis implementasi kebijakan Pusat Kegiatan Lokal dan untuk menganalisis terjadinya pelanggaran alihfungsi peruntukan kawasan dalam kebijakan Pusat Kegiatan Lokal di Kecamatan Cilimus. Metode penelitian bersifat non doktrinal dengan pendekatan socio-legal, karena mengkaji hukum dalam perspektif sosial. Pemerintah Daerah menyusun Rencana Detail Tata Ruang (RDTR) Cilimus sebagai implikasi penetapan Pusat Kegiatan Lokal. Dalam RDTR Cilimus tersebut Pusat Kegiatan Lokal Cilimus dibagi menjadi empat pengembangan kawasan. Namun ketika ketentuan hukum tersebut diberlakukan terdapat kekuatan sosial dan personal dalam proses implementasi Peraturan Daerah Nomor 26 tahun 2011, hal ini menunjukan bahwa Pemerintah Daerah dan masyarakat sebagai pemegang peran, dalam perilakunya tidak saja ditentukan oleh hukum melainkan juga oleh faktor sosial lainya, yaitu faktor ekonomi, faktor politik dan faktor sosial budaya.
\end{abstract}

\title{
Kata kunci : Kebijakan, Pusat Kegiatan Lokal, Pendapatan Asli Daerah
}

\section{A. Latar Belakang}

Kewenangan untuk mengelola penataan ruang dan pemanfaatan ruang telah diatur dalam Undang Undang Nomor 26 Tahun 2007 tentang Penataan Ruang, bahwa ruang wilayah Negara Kesatuan Republik Indonesia sebagai kesatuan wadah yang meliputi ruang darat, laut dan udara, termasuk ruang di dalam bumi maupun sebagai sumber daya. Undang Undang Penataan Ruang juga menjelaskan bahwa 
penataan ruang sebagai suatu sistem perencanaan tata ruang, pemanfaatan ruang, dan pengendalian pemanfaatan ruang merupakan satu kesatuan yang tidak terpisahkan antara yang satu dengan yang lainnya, sehingga diharapkan dapat mewujudkan pemanfaatan ruang yang berhasil guna dan berdaya guna serta mampu mendukung pengelolaan lingkungan hidup yang berkelanjutan. Disamping itu tidak terjadi pemborosan pemanfaatan ruang dan tidak menyebabkan terjadinya penurunan kualitas ruang.

Pengendalian dan pemanfaatan tata ruang di Kabupaten Kuningan berpedoman pada Peraturan Daerah Nomor 26 Tahun 2011 tentang Rencana Tata Ruang Wilayah Kabupaten Kuningan 2011-2031. Rencana tata ruang ini sebagai pedoman dalam menetapkan Rencana Pembangunan Jangka Panjang (RPJP) dan Rencana Pembangunan Jangka Menengah (RPJM) Kabupaten Kuningan. Tujuan utamanya adalah untuk mendukung Kabupaten Kuningan sebagai Kabupaten Konservasi berbasis Pertanian dan Pariwisata yang berdaya saing. Walaupun tidak secara jelas dibuat peraturan mengenai penetapan Kabupaten Kuningan sebagai Kabupaten Konservasi, akan tetapi Pemerintah Daerah telah mengeluarkan norma-norma yang menguatkan Kabupaten Kuningan sebagai Kabupaten Konservasi, diantaranya Peraturan Daerah Nomor 12 Tahun 2007tentang Konservasi Sumber Daya Air, Peraturan Daerah Nomor 11 Tahun 2013 tentang Hutan Kota, serta berbagai berbagai peraturan daerah lainnya.

Pedoman bahwa pengelolaan tata ruang sebagai acuan pembangunan, sering dikesampingkan dan dipaksakan ketika terdapat keinginan untuk melaksanakan pembangunan dengan orientasi meningkatkan Pendapatan Asli Daerah, yang sebenarnya tidak sesuai dengan rencana tata ruang yang berlaku. Seperti halnya kondisi tersebut $\mathrm{di}$ atas minat investasi dalam rangka mendorong meningkatkan laju pertumbuhan ekonomi dan pendapatan daerah seringkali dipandang sebagai dasar untuk merubah atau merevisi rencana tata ruang yang disesuaikan sebagai alat pembenar bagi 
kegiatan investasi. Menurut Esmi Warassih, apabila pembangunan itu merupakan suatu kegiatan untuk melakukan perubahan dalam masyarakat, maka dapat dipahami bahwa peranan pemerintah sebagai lembaga eksekutif menjadi semakin menonjol. Melalui peraturan hukum, pemerintah dapat melaksanakan kebijakan pembangunan, harus diingat bahwa persoalan yang dihadapi pada saat ini bukan sekedar masalah legalitas formal, melainkan tuntutan keadaan yang saat ini menghendaki agar hukum dilihat dalam kerangka yang lebih luas yang sedang berkembang dalam masyarakat. ${ }^{1}$

Realitas ini jelas sangat bertentangan dengan tujuan yang dikehendaki oleh norma Peraturan Daerah Nomor 26 Tahun 2011 tentang Rencana Tata Ruang Wilayah Kabupaten Kuningan. Alasan pokok yang mengakibatkan terjadinya kondisi seperti tersebut diatas diakibatkan oleh proses bekerjanya hukum yang dipengaruhi oleh faktor-faktor metayuridis (non hukum) yaitu faktor kekuatan ekonomi yang dapat mempengaruhi pelaksanaan Peraturan Daerah Nomor 26 tahun 2011. Robert Seidman menyatakan bahwa tindakan apapun yang akan diambil baik oleh para pemegang peran, lembaga pelaksana, maupun pembuat undang-undang selalu berada dalam lingkup kompleksitas kekuatan sosial, budaya, ekonomi, politik dan lain sebagainya. Seluruh kekuatan sosial selalu ikut bekerja dalam setiap upaya untuk memfungsikan peraturan-peraturan yang berlaku, menerapkan sanksinya, dan dalam seluruh aktifitas lembaga pelaksanaannya. ${ }^{2}$

\section{B. Rumusan Masalah}

Berdasarkan uraian latar belakang masalah di atas, maka yang menjadi rumusan masalah yang menjadi fokus kajian dalam penulisan ini adalah :

1. Bagaimanakah kebijakan Pemerintah Daerah dibidang Rencana Tata Ruang Wilayah Kabupaten Kuningan dalam penerapan Pusat Kegiatan

1 Esmi Warassih, Pranata Hukum Sebuah Telaah Sosiologis,(Badan Penerbit Universitas Diponegoro, Semarang, 2011) hlm 111-112.

2 Ibid, hlm 9. 
Lokal Kecamatan Cilimus untuk meningkatkan Pendapatan Asli Daerah beserta faktor-faktor yang mempengaruhinya?

2. Benarkah telah terjadi inkonsistensidalam pelaksanaan kebijakan Tata Ruang untuk Pusat Kegiatan Lokal di Kecamatan Cilimus Kabupaten Kuningan ?

\section{Metode Penelitian}

Metode yang digunakan dalam penelitian ini adalah metode penelitian non dokrtinal. Hal ini disebabkan di dalam penelitian ini hukum tidak hanya dikonsepkan sebagai keseluruhan asas-asas dan kaidah yang mengatur kehidupan manusia dalam masyarakat, melainkan meliputi pula lembaga-lembaga dan proses-proses yang mewujudkan berlakunya kaidah-kaidah itu dalam masyarakat, sebagai perwujudan makna-makna simbolis dari pelaku sosial sebagaimana termanifestasi dan tersimak dalam dan dari aksi dan interaksi antar mereka. ${ }^{3}$ Dengan demikian dalam penelitian ini akan dicoba dilihat keterkaitan antara faktor hukum dengan faktor-faktor ekstra legal yang berkaitan dengan obyek yang diteliti.Pendekatan penelitian yang digunakan untuk membahas permasalahan yang ada adalah socio-legal, hal ini karena memadukan antara pendekatan normatif dan sosiologis. Oleh karena penelitian yang dilakukan terpokus pada implementasi kebijakan Pemerintah Daerah dalam penerapan Pusat Kegiatan Lokal sebagaimana telah ditetapkan dalam Rencana Tata Ruang Wilayah Kabupaten Kuningan 2011-2031.

\section{Pembahasan}

Tujuan utama dibentuknya pemerintah adalah untuk menjaga suatu ketertiban dimana masyarakat bisa menjalani kehidupan secara wajar. Oleh karena itu fungsi utama pemerintah adalah pelayanan pada masyarakat.Sebagaimana dikemukakan oleh Chambliss dan Seidman

3 Soetandyo Wignjosoebroto, Silabus metode penelitian Hukum, Program Pascasarjana Universitas Airlangga, Surabaya, hlm 1-3. 
dalam Teori Bekerjanya Hukum bahwa dalam bekerjanya hukum, peranan dari kekuatan personal dan sosial sangat berpengaruh tidak saja terhadap rakyat sebagai sasaran dari pengaturan hukum, tetapi juga pada lembaga hukum, sebagaimana tergambar dibawah ini $:^{4}$

Judul : Bagan Chamblis \& Seidman yang dimodifikasi

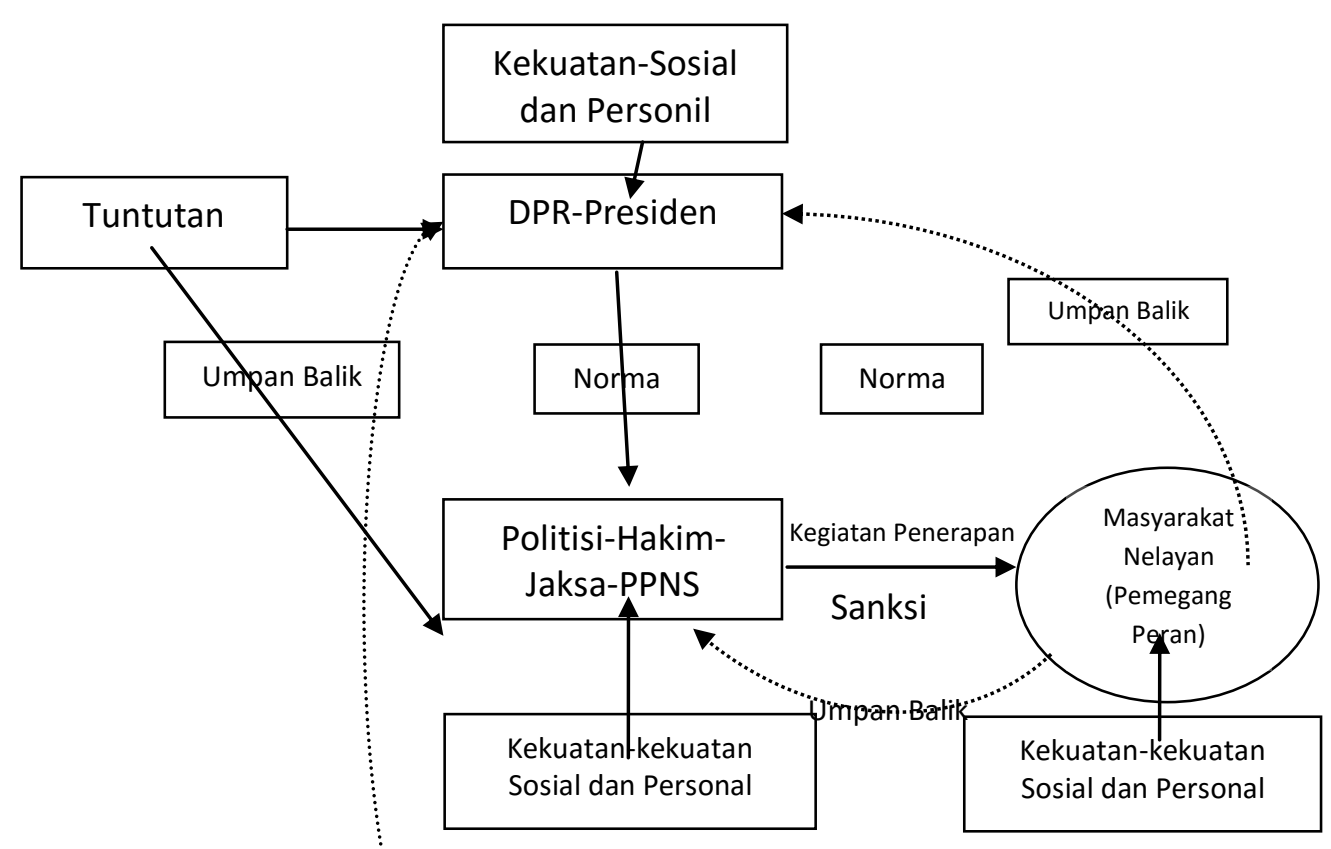

Sumber : Endang Sutrisno, Rekontruksi Budaya Hukum masyarakat nelayan untuk membangun Kesejahteraan Nelayan, hal 114

Berdasarkan bagan tersebut, jelas bahwa terdapat beberapa aspek dalam bekerjanya hukum yaitu: $:^{5}$ lembaga pembuat hukum (law making institutions), lembaga penerap sanksi (sanction activity institutions), pemegang peran (role occupant), serta kekuatan sosietal personal (societal personal force), budaya hukum (legal culture) dan seluruh unsur umpan balik (feed back) dari proses bekerjanya hukum yang sedang terjadi. Ke dalam kekuatan sosial ini termasuk kompleks

4 Esmi Warassih, Op.Cit hlm 10.

5 Endang Sutrisno, Rekontruksi Budaya Hukum masyarakat nelayan untuk membangun kesejahteraan nelayan,(Yogyakarta, Penerbit Genta, 2013) hlm 114. 
tatanan lain. Arah dari tanda panah tersebut, dapat diketahui hasil akhir dari pekerjaan tatanan dalam masyarakat tidak bisa hanya dimonopoli oleh hukum, melainkan juga oleh kekuatan sosial lainnya.

Menurut Hoebel salah satu fungsi dasar hukum adalah memelihara kemampuan masyarakat untuk menyesuaikan diri dengan kondisikondisi kehidupan yang berubah, yaitu dengan cara merumuskan kembali hubungan esensial antara anggota masyarakat. ${ }^{6}$

Hukum yang ideal seyogyanya memenuhi tiga konsep hukum sebagaimana dikatakan oleh Ronny Hanityo Soemitro ${ }^{7}$, yaitu :

1. Hukum sebagai ide-ide nilai moral dan keadilan

2. Hukum sebagai norma, kaidah, peraturan-peraturan, undangundang yang berlaku pada suatu waktu dan tempat tertentu sebagai produk dari kekuasaan negara yang berdaulat; dan

3. Hukum sebagai institusi sosial yang riil dan fungsional dalam sistem kehidupan masyarakat yang terbentuk dari pola tingkah laku yang melembaga.

Dalam suatu masyarakat yang sedang membangun maka akan senantiasa dicirikan oleh suatu perubahan, bagaimanapun kita mendefinisikan pembangunan tersebut dan apapun indikator yang kita pergunakan untuk masyarakat dalam pembangunan adalah untuk dapat menjamin agar perubahan yang terjadi dan dialami oleh masyarakat tersebut dapat dilalui dengan cara teratur. ${ }^{8}$

Kebijakan daerah sangat diperlukan untuk dapat menjadi landasan dalam membangun masyarakat baik pembangunan fisik maupun spiritual, namun menurut $\boldsymbol{A}$ Hoogerwerf suatu kebijakan disebut kebijakan publik dapat dilihat dari dua unsur, yaitu $:^{9}$

Esmi Warassih,Op.Cit, hlm 24.

Ronny Hanityo Soemitro, Perspektif Sosial Dalam Pemahaman Masalah-Masalah Hukum (Semarang, Penerbit CV Agung, 1989) hlm 1.

8 Endang Sutrisno, Budaya Hukum Dalam Melindungi Pencemaran Lingkungan (Cirebon, Swagati Press), 2007, hlm 11.

9 Bambang Sunggono, Hukum dan Kebijakan Publik, (Sinar Grafika, Jakarta, 1994) hlm 21. 
1. Kebijakan publik mengenai langsung atau tidak langsung semua anggota masyarakat di daerah kekuasaan tertentu;

2. Kebijakan publik mengikat bagi anggota masyarakat di daerah kekuasaan tertentu, juga karena disebabkan kebijaksanaan publik mengikat, maka selalu timbul pertanyaan apa yang menjadi atau harus menjadi ukuran kebijaksanaan itu.

Menurut Thomas $\mathbf{R}$ Dye ${ }^{10}$, kebijakan publik adalah 'whatever governments choose to do or not to do" yaitu apa yang akan diperbuat oleh pemerintah melakukan atau tidak melakukan. David Easton melukiskannya sebagai pengaruh dari aktifitas pemerintah. ${ }^{11}$

Menurut Esmi Warassih, ${ }^{12}$ tidak ada definisi kebijakan yang sama, namun beberapa definisi yang diajukan menunjukan adanya beberapa unsur yang harus ada, yaitu nilai, tujuan dan sarana. Salah satu sarana yang banyak dipilih adalah peraturan perundang-undangan. Oleh sebab itu pada hakikatnya hukum pun mengandung nilai, konsep-konsep dan tujuan. Suatu kebijakan dibuat atau dikeluarkan tentunya berisi harapan-harapan yang hendak dilakukan oleh subyek hukum sebagai pemegang peran, maka kebijakan memerlukan adanya strategi dan taktik. Sejalan dengan pemikiran ini, Irfan Aslamy mengemukakan, ${ }^{13}$ bahwa suatu kebijaksanaan memuat tiga elemen, yaitu :

1. Identifikasi dari tujuan yang ingin dicapai;

2. Taktik dan strategi dari berbagai langkah untuk mencapai tujuan yang diinginkan;

3. Penyediaan berbagai input untuk memungkinkan pelaksanaan secara nyata dari taktik dan strategi.

10 George Ritzer, Sosiologi IImu Pengetahuan Berparadigma (disadur Alimandan) Jakarta, Penerbit Rajawali Pers, 1992) hlm 53-54

11 Riant Nugroho, Op.Cit, hlm 3.

12 Endang Sutrisno, Op.Cit hal 113.

13 Irfan Aslamy, Prinsip-Prinsip Perumusan Kebijakan Negara, Bandung, Bumi Aksara, hlm 17. 
Selain itu pembuat hukum harus bersungguh-sungguh untuk mengikuti persaratan-persaratan tertentu, Lon Fuler menunjukan delapan prinsip legalitas(Principles of Legality) yang harus diikuti dalam membuat hukum, yaitu : ${ }^{14}$

1. Sistem hukum harus mengandung peraturan-peraturan artinya ia tidak boleh mengandung sekedar keputusankeputusan yang bersifat ad hoc

2. Peraturan-peraturan yang telah dibuat itu harus diumumkan

3. Peraturan itu tidak boleh berlaku surut

4. Peraturan-peraturan disusun dalam rumusan yang bisa dimengerti

5. Suatu sistem tidak boleh mengandung peraturan-peraturan yang bertentangan satu sama lain,

6. Peraturan-peraturan tidak boleh mengandung tuntutan yang melebihi apa yang dapat dilakukan.

7. Peraturan-peraturan harus tetap tidak boleh sering diubahubah

8. Harus ada kecocokan antara peraturan yang diundangkan dengan pelaksanaannya sehari-hari.

Mengacu pada proses pembuatan kebijakan publik, David Easton mengatakan bahwa pembentukan kebijakan sebagai output, dapat dideskripsikan melalui Model Kotak Hitam Easton-ian. Karkteristik utama model Easton-ian adalah model ini melihat proses kebijakan dari segi input yang diterima, dalam bentuk aliran dari lingkungan, dimediasi melalui saluran input (partai, media, kelompok kepentingan), permintaan di dalam sistem politik (withinputs) dan konversinya menjadi outputdan hasil kebijakan. ${ }^{15}$ Proses transformasi dari keinginan-keinginan sosial menjadi peraturan perundang-undangan baik dalam konteks politik dan sosiologis, tidak hanya terjadi pada saat pembentukan suatu

14 Endang Sutrisno, Op. Cit hal 95.

${ }^{15}$ Wayne Parsons, Public Policy:Pengantar Teori dan Praktek Analisis Kebijakan( dialihbahasakan oleh Tri Wibowo Budi Santoso) 2008, hlm 25. 
peraturan, dalam tahap bekerjanya pun proses-proses tersebut berlangsung terus dan mengoreksi secara terus menerus.

Arnstein dengan teori klasiknya "delapan tangga peran serta masyarakat" menggambarkan peran serta masyarakat ke dalam tiga tingkatan berdasarkan tingkat kehakikiannya, yaitu:

a. Tingkat non partisipasi, yaitu tingkat di mana tujuan dari peran serta masyarakat adalah mendidik dan mengatasi masyarakat yang berperan serta.

b. Tingkat tekonisme (menyampaikan informasi, konsekuensi dan pedoman), yaitu masyarakat di dengar dan di perkenankan berpendapat tetapi mereka tidak memiliki kemampuan dan mendapatkan jaminan bahwa pandangan mereka akan di pertimbangkan secar sungguh-sungguh oleh penentu kebijakan.

c. Tingkat kekuatan masyarakat, (kemitraan,pendelegasian kekuasaan dan pengawasan masyarakat). Dalam hal ini masyarakat memiliki pengaruh dalam proses pengambilan keputusan dengan menjalankan kemitraan dengan kesetaraan kekuatan atau pendelegasian kekuasaan dan pengawasan masyarakat. ${ }^{16}$

Kondisi untuk selalu menjaga keseimbangan dan keserasian antara berbagai pihak, maka dinamika kegiatan pembangunan dapat di arahkan kepada kegiatan dan kesejahteraan bagi masayarakat dengan memperhatikan stabilitas sebagai salah satu tujuan hukum. Untuk itu harus memperhatikan adanya 2 (dua) masa, yaitu masa sebelum program itu diimplementasikan dan masa sesudah kebijaksanaan pemerataan di laksanakan. Hasil dari dua masa tersebut diperbandingkan untuk mengetahui perubahan atau pengaruh apakah yang telah terjadi akibat kebijaksanaan pemerataan itu diimplementasikan. ${ }^{17}$

16 Sirajudin,dkk. Hak Rakyat mengontrol Negara, (Jakarta, Malang Corruption Watch, 2006), hlm 98.

17 Esmi Warassih, Op.Cit hlm 136. 


\section{E. Implementasi Kebijakan Pemerintah Daerah Dalam Bidang Rencana} Tata Ruang : Studi Kritis terhadap inkonsistensi kebijakan fungsi lahan di Kecamatan Cilimus

Kebijakan Pemerintah Daerah sebagaimana tertuang dalam Rencana Detail Tata Ruang (RDTR) Kecamatan Cilimus dibagi atas empat bagian kawasan perkotaan. Masing-masing bagian pengembangan kawasan perkotaan sebagai berikut : ${ }^{18}$

\section{Pengembangan Kawasan Bagian Utara}

Kawasan perkotaan bagian Utara diarahkan untuk pengembangan permukiman perkotaan, terutama untuk pengembangan perumahan oleh developer. Pengembangan perumahan tersebut diprioritaskan untuk memenuhi kebutuhan masyarakat Cilimus, untuk itu type rumah harus disesuaikan dengan kemampuan daya beli masyarakat Cilimus.

Pengembangan kegiatan di kawasan perkotaan bagian Utara akan lebih banyak untuk memenuhi kebutuhan masayarakat di kawasan tersebut, atau skala pelayanan lokal, yang meliputi perdagangan dan jasa, perkantoran, dan pusat pelayanan fasilitas perkotaan. Luas kawasan perkotaan bagian Utara adalah 185,367 ha, mencakup sebagian wilayah Desa Sampora dan Desa Cilimus.

\section{Pengembangan Pusat Kawasan Perkotaan}

Pusat kawasan perkotaan merupakan kawasan dengan intensitas kegiatan yang tinggi, efisiensi dalam pemanfaatan lahan perkotaan juga tinggi, sehingga memiliki kepadatan yang tinggi. Perluasan kawasan pusat perkotaan sudah sangat diperlukan, yaitu dengan meningkatkan aksesibilitas atau pelebaran jalan ke arah timur sampai rencana jalan baru. Pelebaran jalan akan menciptakan kawasan potensial baru dan ber-kembangnya perkantoran kecamatan. Pada kawasan bagian timur dengan didukung jalan alternatif regional yang baru menghubungkan

18 Rencana Detail Tata Ruang (RDTR) Kecamatan Cilimus. 
Sampora - Cilimus - Sangkanhurip, maka pada kawasan tersebut sangat potensial sebagai lokasi pengembangan terminal agribisnis.

Pengembangan kegiatan di pusat kawasan perkotaan adalah untuk memenuhi fungsi perkotaan Cilimus sebagai pusat pengembangan wilayah bagi wilayah hinterland-nya, dengan skala pelayanan regional yang meliputi perdagangan dan jasa, terminal agribisnis, perkantoran, transportasi dan pusat pelayanan fasilitas perkotaan skala regional. Luas pusat kawasan perkotaan adalah 191,853 ha, mencakup sebagian wilayah Desa Caracas, Cilimus, dan Bojong.

\section{Pengembangan Kawasan Bagian Tengah}

Kawasan perkotaan bagian Tengah posisi lokasinya diapit diantara Kawasan Pariwisata Sangkanhurip dan Kawasan Pariwisata Linggajati, arahan pengembangan kegiatan di kawasan tersebut harus terkait dan mendukung fungsi pariwisata yang ada disekitarnya. Pemanfaatan ruang dominan untuk Ruang Terbuka Hijau (RTH), diantaranya Rest Area, Taman Parkir, Taman Kota, Taman Bermain, Pusat Jajanan Cinderamata dan Oleh-Oleh,

Kawasan perkotaan bagian Tengah bukan merupakan kawasan ekslusif untuk mendukung pariwisata secara tertutup, sehingga kegiatan-kegiatan lain seperti permukiman dan pendukungnya masih dapat berkembang didalamnya. Pengembangan kegiatan di kawasan perkotaan bagian Tengah terkait fungsinya sebagai pendukung pariwisata dan kawasan permukiman, maka kegiatan yang dikembangkan meliputi jasa pendukung pariwisata, perdagangan dan jasa, kesehatan dan pusat pelayanan fasilitas perkotaan skala lokal. Luas kawasan perkotaan bagian Tengah adalah 137,566 ha, mencakup sebagian wilayah Desa Bojong dan Desa Bandorasa Wetan.

\section{Pengembangan Kawasan Bagian Selatan}

Penggunaan lahan di kawasan perkotaan bagian Selatan untuk kegiatan permukiman akan sangat dibatasi karena adanya areal sawah beririgasi teknis. Pengembangan kegiatan di kawasan perkotaan bagian 
Selatan meliputi jasa pendukung pariwisata, agro industri, agribisnis dan pengolahan hasil pertanian dan perkebunan. Luas kawasan perkotaan bagian Selatan adalah 185,567 ha, mencakup wilayah Desa Bandorasa Wetan.

Penetapan empat kawasan dalam Pusat Kegiatan Lokal Cilimus adalah implementasi kebijakan publik. Diharapkan sesuai dengan tujuan Peraturan Daerah Tentang Rencana Tata Ruang Wilayah Kabupaten Kuningan, kebijakan tersebut akan mendorong Kecamatan Cilimus menjadi daerah yang maju dan menjadi pusat kegiatan pariwisata di Kabupaten Kuningan sehingga dapat memberikan kontribusi untuk peningkatan PAD Kabupaten Kuningan. Namu seperti yang dikemukakan oleh Brian W Hoogwood dan Lewis A Gun, ${ }^{19}$ bahwa untuk melakukan implementasi kebijakan diperlukan beberapa syarat yaitu jaminan kondisi eksternal yang dihadapi oleh badan pelaksana tidak menimbulkan masalah besar, dan tersedianya sumber daya yang memadai. Nyatanya semua syarat yang dibutuhkan untuk pelaksanaan implementasi kebijakan tidak terpenuhi. Tidak jelasnya arah rencana pembangunan dan koordinasi antar SKPD di Kabupaten Kuningan serta belum ditetapkannya Rencana Detail Tata Ruang (RDTR) Cilimus dalam suatu Peraturan Daerah menjadi kendala dalam pelaksanaan kebijakan. Hal ini pula yang diingatkan oleh Van Meter dan Van Horn ${ }^{20}$ bahwa standar dan sasaran kebijakan, sumber daya, karakteristik organisasi pelaksana, komunikasi antar organisasi, sikap para pelaksana serta lingkungan sosial politik akan menjadi faktor penentu kebijakan.

Hasil penelitian di wilayah studi, dapat dideskripsikan bahwa kebijakan yang dibuat oleh Pemerintah Daerah belum berpedoman kepada Rencana Detail Tata Ruang (RDTR) Kecamatan Cilimus yang telah disusun. Ini menunjukan sebagaimana dikemukakan oleh Chamblis

19 Riant Nugroho, Public Policy: Teori, Manajemen, Dinamika, Analisis, Konvergensi, dan Kimia Kebijakan, (Jakarta, PT Elex Media Komputindo, 2014), hlm 174.

20 Ibid, hlm 174. 
dan Seidman ${ }^{21}$ bahwa terdapat faktor-faktor atau kekuata-kekuatan yang bersifat personal dan sosial yang berupaya untuk mempengaruhi Pemerintah Daerah dalam membuat kebijakan dalam menerapkan rencana tata ruangnya. Faktanya telah terjadi pelanggaran alih fungsi peruntukan hampir di seluruh kawasan pengembangan terutama di kawasan perkotaan Cilimus bagian selatan. Dalam Rencana Detail Tata Ruang sebagaimana tersebut di atas, kawasan ini arahannya untuk pengembangan pendukung kegiatan pariwisata, agribisnis dan pengolahan hasil pertanian dan perkebunan. Sedangkan untuk pengembangan pemukiman cenderung ditutup atau sangat dibatasi karena adanya areal sawah beririgasi teknis. Akan tetapi data yang diperoleh dari Dinas Tata Ruang dan Cipta Karya Kabupaten Kuningan ${ }^{22}$ memperlihatkan kondisi yang berlainan. Saat ini sedikitnya ada 11 (sebelas) perusahaan pengembang yang sedang berinvestasi di sekitar wilayah Cilimus, sebagaimana tabel dibawah ini :

\begin{tabular}{|c|c|c|c|c|c|}
\hline No & $\begin{array}{c}\text { Nama } \\
\text { Pemohon/Pengemba } \\
\text { ng }\end{array}$ & Lokasi & Untuk Bangunan & $\begin{array}{l}\text { Luas } \\
\text { Tanah }\end{array}$ & $\begin{array}{c}\text { Tgl } \\
\text { ditetapkan }\end{array}$ \\
\hline 1 & PT CPP & $\begin{array}{ll}\text { Desa } & \text { Sampora } \\
\text { Cilimus } & \end{array}$ & $\begin{array}{l}\text { Perumahan } \\
\text { Panorama Bukit } \\
\text { Halimpu }\end{array}$ & $\begin{array}{r}3.762 \\
\mathrm{~m} 2\end{array}$ & $\begin{array}{lr}2 & \text { Maret } \\
2011 & \end{array}$ \\
\hline 2 & PT DI & $\begin{array}{l}\text { Desa Bandorasa } \\
\text { Wetan Cilimus }\end{array}$ & $\begin{array}{l}\text { Perumahan Griya } \\
\text { Wisata Kuningan }\end{array}$ & $\begin{array}{r}30.000 \\
\mathrm{~m} 2\end{array}$ & $\begin{array}{l}2 \text { Agustus } \\
2011\end{array}$ \\
\hline 3 & PT SP & $\begin{array}{l}\text { Desa } \\
\text { Karangmuncang } \\
\text { Cilimus } \\
\end{array}$ & $\begin{array}{l}\text { Perumahan Graha } \\
\text { Mas }\end{array}$ & $\begin{array}{r}4.009 \\
\mathrm{~m} 2\end{array}$ & $\begin{array}{l}22 \\
\text { September } \\
2011\end{array}$ \\
\hline 4 & Ir. WS & $\begin{array}{l}\text { Desa Caracas } \\
\text { Cilimus }\end{array}$ & $\begin{array}{l}\text { Perumahan } \\
\text { Caracas Mountain } \\
\text { View }\end{array}$ & $\begin{array}{r}33.400 \\
m 2\end{array}$ & $\begin{array}{ll}26 & \text { April } \\
2011 & \end{array}$ \\
\hline 5 & $D E, S E$ & $\begin{array}{l}\text { Desa Bandorasa } \\
\text { Wetan Cilimus }\end{array}$ & $\begin{array}{l}\text { Perumahan } \\
\text { Panorama }\end{array}$ & $\begin{array}{r}18.218 \\
m 2\end{array}$ & $\begin{array}{ll}30 & \text { Juni } \\
2011 & \end{array}$ \\
\hline
\end{tabular}

21 Endang Sutrisno, Kontruksi Budaya Hukum Masyarakat Nelayan Untuk membangun Kesejahteraan Nelayan (Yogyakarta, Genta Publishing, 2013), hlm 114.

22 Data Perumahan di Kabupaten Kuningan Tahun 2011-2014, Dinas Tata Ruang dan Cipta Karya Kabupaten Kuningan. 


\begin{tabular}{|c|c|c|c|c|c|}
\hline & & & Bandorasa & & \\
\hline 6 & PT DI & $\begin{array}{l}\text { Desa Bandorasa } \\
\text { Wetan Cilimus }\end{array}$ & $\begin{array}{l}\text { Perumahan Griya } \\
\text { Wisata Kuningan }\end{array}$ & $\begin{array}{r}30.000 \\
m 2\end{array}$ & $\begin{array}{l}9 \text { Oktober } \\
2012\end{array}$ \\
\hline 7 & PT DI & $\begin{array}{l}\text { Desa Bandorasa } \\
\text { Wetan Cilimus }\end{array}$ & $\begin{array}{l}\text { Perumahan Griya } \\
\text { Wisata Kuningan }\end{array}$ & $\begin{array}{r}30.500 \\
\mathrm{~m} 2\end{array}$ & $\begin{array}{ll}4 & \text { Maret } \\
2013 & \end{array}$ \\
\hline 8 & $C V G B A$ & $\begin{array}{l}\text { Desa Nanggela } \\
\text { Mandirancan }\end{array}$ & $\begin{array}{l}\text { Perumahan Era } \\
\text { Griya Sae }\end{array}$ & $\begin{array}{r}11.800 \\
\mathrm{~m} 2\end{array}$ & $\begin{array}{ll}27 & \text { Mei } \\
2013 & \end{array}$ \\
\hline 9 & JJ & $\begin{array}{l}\text { Desa } \\
\text { Randobawailir } \\
\text { mandirancan }\end{array}$ & $\begin{array}{l}\text { Perumahan } \\
\text { Dangdeur Village }\end{array}$ & $1.380 \mathrm{~m} 2$ & $\begin{array}{l}13 \quad \text { Maret } \\
2014\end{array}$ \\
\hline 10 & PT CGH & $\begin{array}{l}\text { Desa Caracas } \\
\text { Cilimus }\end{array}$ & $\begin{array}{l}\text { Perumahan Graha } \\
\text { Pesona Caracas }\end{array}$ & $6.319 \mathrm{~m} 2$ & $\begin{array}{ll}30 & \text { April } \\
2014 & \end{array}$ \\
\hline 11 & PT GA & $\begin{array}{ll}\text { Desa Sampora } \\
\text { Cilimus }\end{array}$ & $\begin{array}{l}\text { Perumahan Grage } \\
\text { Manoa Estate }\end{array}$ & $\begin{array}{r}46.122 \\
\mathrm{~m} 2\end{array}$ & $\begin{array}{l}26 \\
\text { November } \\
2014\end{array}$ \\
\hline
\end{tabular}

Sumber : Dinas Tata Ruang danCipta Karya Kabupaten Kuningan

Data di atas menunjukan bahwa ada inkonsisten dalam kebijakan di bidang tata ruang di Kabupaten Kuningan. Implikasinya tentu sangat luas tidak saja pada bidang ekonomi, tetapi juga pada bidang-bidang lainnya. Mengacu pada proses pembuatan kebijakan David Easton melalui Model Kotak Hitam Estonian ${ }^{23}$ dapat dideskripsikan bahwa kebijakan sebagai suatu output dipengaruhi oleh input yang di dalamnya terdapat pihakpihak yang terlibat dalam proses tersebut dan sangat bergantung pada sistem politik. Proses yang cukup panjang ini merupakan proses transformasi dari beberapa tuntutan ke dalam suatu keputusan yang otoritatif. ${ }^{24}$ Ketidakpatuhan pada suatu peraturan telah menyebabkan Kuningan banyak mengalami kehilangan lahan pertanian yang beririgasi sehingga dalam tiga tahun terakhir lahan sawah menyusut seluas 262 hektar atau dari semula 29.078 hektar menjadi 28.816 hektar. ${ }^{25}$

Peraturan Daerah Nomor 26 Tahun 2011 pada tataran pelaksanaannya tidak sesuai dengan semangat awal yaitu untuk mendukung Kabupaten

23 Endang Sutrisno, Op.cit hlm 280.

24 Esmi Warassih, Op.Cit, hlm 44.

25 Keterangan Kepala Dinas Pertanian Kabupaten Kuningan sebagaimana termuat dalam Harian Umum Radar Cirebon, tanggal 10 Desember 2014. 
Kuningan sebagai Kabupaten Konservasi dan sekaligus dapat meningkatkan kesejahteraan masyarakatnya melalui peningkatan pendapatan asli daerah. Adanya pengaruh atau kekuatan sosial dan personal sebagaimana dikemukakan oleh Chambliss dan Robert Seidman sangat jelas dalam implementasi kebijakan tata ruang di Kabupaten Kuningan sebagaimana diatur dalam Peraturan Daerah tersebut. Pengaruh sosial berupa kontrol dari masyarakat terhadap kebijakan yang dirumuskan oleh Pemerintah Daerah dalam hal ini Bupati dan DPRD, pada akhirnya tidak terjadi karena kekuatan personal lebih dominan dibandingkan kekuatan sosial.

Dominasi kekuatan personal dalam penerapan kebijakan tata ruang dapat terlihat dari keinginan kuat Pimpinan Daerah (Bupati) untuk memacu peningkatan PAD Kabupaten Kuningan yang masih rendah. Tahun 2013, PAD Kabupaten Kuningan baru mencapai Rp 120 miliar sedangkan APBD Kabupaten Kuningan mencapai lebih dari 1,2 triliun. Ini artinya kontribusi PAD terhadap APBD masih sangat rendah. Oleh karena itu pihak DPRD mentargetkan kepada Bupati untuk terus meningkatkan PAD, dan pada tahun 2016, PAD Kabupaten Kuningan ditargetkan mencapai Rp 200 miliar. $^{26}$

Sebagai norma hukum, Peraturan Daerah Nomor 26 Tahun 2011 sudah dilengkapi dengan perangkat sansi-sanksi baik administrasi, pidana maupun perdata. Namun kenyataannya pelanggaran alih fungsi lahan tersebut tetap terjadi tanpa ada upaya pengenaan sanksi bagi para pelanggarnya. tidak efektifnya pengawasan Badan Koordinasi Penataan Ruang Daerah (BKPRD) yang dipimpin oleh Sekertaris Daerah sebagai lembaga yang dibentuk untuk pengawasan dan evaluasi pelaksanaan Tata Ruang menjadi salah satu faktor terjadinya penyimpangan terhadap perencanaa tata ruang di Pusat Kegiatan Lokal Cilimus. Padahal BKPRD adalah badan yang bersifat adhoc yang dibentuk untuk mendukung

26 Simpulan dari hasil Wawancara Pribadi dengan Kepala Dinas Pendapatan Daerah Kabupaten Kuningan, pada tanggal 18 Juni 2015. 
pelaksanaan Undang Undang Nomor 26 Tahun 2007 dan Peraturan Daerah Nomor 26 Tahun 2011.

Ketidakkonsistenan Pemerintah Daerah Kabupaten Kuningan dalam penerapan kebijakan tata ruang disebabkan juga karena tidak dirumuskannya Rencana Detail Tata Ruang (RDTR) Cilimus dalam suatu Peraturan Daerah sehingga tidak memiliki legalitas. Menurut Thomas $R$ Dye, ${ }^{27}$ kebijakan tidak dapat menjadi kebijakan publik kalau tidak dirumuskan, disahkan dan dilaksanakan oleh lembaga pemerintah. Riant Nugroho menggambarkan bagaimana kebijakan yang dibuat dapat dilaksanakan atau tidak bergantung pada sumber daya yang tersedia serta memperhatikan prinsip-prinsip good government yaitu transparansi, akuntabilitas, adil, dan bertanggung jawab. ${ }^{28}$

Kepastian penataan ruang merupakan permasalahan di daerah, kebijakan ini mendesak dilaksanakan sebab banyak permasalahan di daerah yang bersumber dari pelanggaran tata ruang. Secara umum, penataan tata ruang di Jawa Barat belum optimal, bahkan cenderung inkonsisten yang menyebabkan terjadinya alih fungsi lahan. Hal ini juga disorot oleh Pemerintah Pusat melalui Kementerian Agraria dan Tata Ruang ${ }^{29}$ yang melihat belum ada keselarasan dalam penataan tata ruang dan wilayah di Jawa Barat, sehingga Pemerintah Pusat meminta agar Pemerintah Provinsi Jawa Barat dan seluruh Kabupaten/Kota di Jawa Barat untuk lebih cermat dalam menyusun rencana tata ruangnya. Untuk itu diperlukan komitmen dan kosistensi seluruh sektor pembangunan. Hal ini dimaksudkan untuk mewujudkan harmonisasi program pembangunan separsial dengan Rencana Pembangunan Jangka Menengah Daerah melalui sinkronisasi program pemanfaatan ruang dan instrumen pengendaliannya.Tujuan utama dari penataan ruang adalah bukan hanya dimaksudkan untuk mewujudkan suatu kota atau daerah di Indonesia

27 Riant Nugroho, Op.Cit hlm 164.

28 Ibid, hlm 164.

29 Pernyataan Menteri Agraria dan tata Ruang Fery Mursidan Baldan dalam Berita HU Pikiran rakyat, Sabtu 23 Mei 2015, hlm 24. 
tidak tumbuh semerawut dan tidak enak di pandang mata tetapi juga menghindari timbulnya kerusakan lingkungan dan bahaya ancaman bencana alam.

Mencermati kondisi tersebut di atas, terlihat bahwa Pemerintah Daerah berada dalam situasi dilematis dalam menentukan kebijakan berkaitan dengan upaya untuk meningkatkan Pendapatan Asli Daerah (PAD), karena besarnya tekanan legislatif (DPRD) kepada eksekutif (Pemerintah Daerah) untuk terus memacu peningkatan Pendapatan Asli Daerah (PAD). Sehingga menimbulkan pertanyaan, model kebijakan publik seperti apa yang diterapkan pada persoalan peningkatan Pendapatan Asli Daerah yang selama ini hanya mengandalkan dari obyek pajak dan retribusi daerah saja. Berpijak pada karakter pengambilan kebijakan yang pada implementasinya tidak sensitif terhadap kepekaan sosial kiranya dapatlah kebijakan publik yang dilakukan oleh pemerintah daerah mengacu pada Model Elit Massa, ${ }^{30}$ merupakan model dimana kelompok kecil masyarakat adalah pemegang kekuasaan. Elit massa dianggap mengetahui tentang kebutuhan massa. Implikasi dari teori ini adalah para elit menerapkan kebijakan publik tidak sebagai refleksi atau merupakan tuntutan masyarakat tetapi implementasinya lebih banyak demi kepentingan elit itu sendiri. Dengan demikian definisi kebijakan publik merupakan hasil definisi dari para elit, dan para elit berpandangan bahwa massa atau masyarakat lebih banyak apatis dan sering dimanipulasi oleh elit.

Posisi Kecamatan Cilimus sebagai Pusat Kegiatan Lokal di Kabupaten Kuningan seharusnya dikembalikan kepada rencana awal sesuai dengan arahan tata ruangnya sebagai sentra industri pariwisata. Wilayah Cilimus yang terdiri atas perbukitan lereng, lembah dan daratan yang indah sangat kaya akan obyek wisata dan daya tarik wisata yang alami dan menyegarkan. Menurut data dari Dinas Pariwisata dan Kebudayaan

30 Wayne Parsons, Public Policy: Pengantar, Teori dan Praktek Analisis Kebijakan (dialihbahasakan oleh Tri Wibowo Budi Santoso), (Jakrta, PT Kencana, 2008), hlm 143. 
Kabupaten Kuningan, ${ }^{31}$ banyak sekali obyek wisata yang bisa dikembangkan di Kecamatan Cilimus dan akan mampu menarik kunjungan wisatawan Nusantara dan Mancanegara.

Berkaitan dengan hal tersebut maka Kebijakan Pusat Kegiatan Lokal Cilimus harus memperhatikan :

a. Peraturan itu sendiri, artinya Peraturan Daerah Nomor 26 Tahun 2011 Tentang Rencana Tata Ruang Wilayah Kabupaten Kuningan 2011-2031 yang menetapkan Cilimus sebagai Pusat Kegiatan Lokal harus segera diimplementasikan dengan membuat Peraturan Daerah Tentang Rencana Detail Tata Ruang (RDTR) Cilimus.

b. Petugas yang menerapkan peraturan hukum harus menunaikan tugasnya dengan baik, jujur dan memahami tujuan dibuatnya Rencana Tata Ruang di kabupaten Kuningan yaitu untuk mendukung Kabupaten Kuningan sebagai Kabupaten Konservasi.

c. Fasilitas yang ada diharapkan akan dapat mendukung pelaksanaan hukum, hal ini berkaitan dengan mekanisme dan standard operasional prosedur (SOP) di bidang perijinan yang melibatkan antar Satuan Kerja Perangkat Daerah

d. Warga masyarakat yang menjadi sasaran peraturan tersebut akan bertindak dalam merespon norma hukum sebagai fungsi aturan yang berlaku, sanksinya, kegiatan institusi penegakan hokum dan keseluruhan kompleks kekuatan social politik serta kekuatan lain yang mempengaruhi.

Uraian di atas sesuai juga dengan Purbacaraka dan Soerjono Soekanto, ${ }^{32}$ pokok penegakan hukum sebenarnya terletak pada faktorfaktor yang mungkin mempengaruhinya yaitu faktor hukumnya sendiri, faktor penegak hukumnya, faktor sarana dan prasarana serta faktor kebudayaan.

31 Hasil wawancara dengan Kepala Dinas Pariwisata dan Kebudayaan Kabupaten Kuningan, tanggal 19 Mei 2015.

32 Kompasiana, Faktor-faktor yang mempengaruhi Penegakan Hukum. 
F. Konsekuensi Yuridis terhadap Pelanggaran Kebijakan Alihfungsi di Kawasan Pusat Kegiatan Lokal Cilimus

Adanya pemberian ijin berkaitan dengan kebijakan alih fungsi peruntukan lahan pertanian menjadi perumahan merupakan hubungan hukum. Karena menyangkut dua pihak yang berhubungan. Oleh karena itu terhadap pelanggaran-pelanggaran tersebut dapat menimbulkan konsekuensi yuridis berupa penerapan sanksi yang dapat dikenakan pada para pihak yang melakukan pelanggaran terhadap ketentuan tersebut, adapun sanksi yang dapat dikenakan berupa sanksi administratif, sanksi perdata, dan sanksi pidana.

\section{Sanksi Administratif}

Sanksi Administratif diatur dalam Pasal 61 sampai dengan 63 Undang Undang Penataan Ruang. Pasal 61 Undang Undang Nomor 26 Tahun 2007 menerangkan bahwa setiap orang wajib untuk mentaati rencana tata ruang yang telah ditetapkan, memanfaatkan ruang sesuai dengan ijin pemanfaatan ruang dari pejabat yang berwenang, mematuhi ketentuan yang telah ditetapkan dalam persaratam ijin pemanfatan ruang, dan memberikan akses terhadap kawasan yang oleh ketentuan peraturan perundang-undangan dinyatakan sebagai milik umum.

Pelanggaran terhadap ketentuan tersebut memiliki implikasi berupa sanksi administratif, dalam bentuk :

a. Peringatan tertulis

b. Penghentian sementara kegiatan

c. Penghentian sementara pelayanan umum

d. Penutupan lokasi

e. Pencabutan ijin

f. Pembatalan ijin

g. Pembongkaran bangunan

h. Pemulihan fungsi ruang, dan

i. Denda administratif. 
Selanjutnya dalam Pasal 108 Peraturan Daerah Nomor 26 Tahun 2011 Tentang Rencana Tata Ruang Wilayah Kabupaten Kuningan 2011-2031 mengatur mengenai tata cara pengenaan sanksi adninistratif, meliputi :

a. Peringatan tertulis dapat dilaksanakan dengan prosedur bahwa pejabat yangberwenang dalam penertiban pelanggaran pemanfaatan ruang dapat memberikan peringatan tertulis melalui penerbitan surat peringatan tertulis sebanyak-banyaknya tiga kali.

b. Penghentian sementara dapat dilakukan melalui penerbitan surat pengehntian kegiatan sementara, apabila surat penghentian sementara ini diabaikan maka pejabat yang berwenang menerbitkan surat keputusan mengenai sanksi penghentian secara paksa.

c. Penghentian sementara pelayanan umum dapat dilakukan melalui penerbitan surat pemberitahuan penghentian sementara pelayanan umum, apabila diabaikan pejabat yang berwenang melakukan tindakan penertiban dengan memberitahukan kepada pelanggar mengenai pengenaan sanksi dan jenis pelayanan yang akan diputus.

d. Penutupan lokasi dapat dilakukan melalui penerbitan surat perintah penutupan lokasi dari pejabat yang berwenang, apabila pelanggar mengabaikan maka pejabat yang berwenang menerbitkan surat keputusanpengenaan sanksi penutupan lokasi kepada pelanggar.

e. Pencabutan ijin dapat dilakukan melalui menerbitkan surat pemberitahuan sekaligus pencabutan ijin oleh pejabat, apabila diabaikan, maka pejabat yang berwenang melakukan tindakan penertiban kegiatan tanpa ijin sesuai peraturan perundang-undangan.

f. Pembatalan ijin dilakukan melalui membuat lembar evaluasi yang berisikan dengan arahan pola pemanfaatan ruang dalam rencana tata ruang yang berlaku, memberitahukan kepada pihak yang memanfaatakan ruang perihak rencana pembatalan ijin, menerbitkan surat keputusan pembatalan ijin, serta memberritahukan kepada pemanfaat ruang mengenai status ijin yang telah dibatalkan. 
9. Pembongkaran bangunan dilakukan melalui penerbitan surat pemberitahuan perintah pembongkaran bangunan dari pejabat yang berwenang melakukan penerbitan, apabila diabaikan, pejabat yang berwenang melakukan penertiban mengeluarkan surat keputusan mengenai sanksi pembongkaran bangunan.

h. Pemulihan fungsi ruang dapat dilakukan melalui menentapkan ketentuan pemulihan fungsi ruang yang berisi bagian-bagian yang harus dipulihkan fungsinya dan cara pemulihannya, pejabat yang berwenang melakukan penertiban pelanggaran pemanfaatan ruang dan menerbitkan surat pemberitahuan perintah pemulihan fungsi ruang.

i. Denda administratif dapat dikenakan secara tersendiri atau bersama-sama dengan pengenaan sanksi administratif.

Ketentuan sebagaimana tersebut di atas sebenarnya sudah lengkap dan berupaya untuk melaksanakan fungsi hukum sebagai sosial control terhadap masyarakat, khususnya di Kabupaten Kuningan. Akan tetapi temuan di wilayah studi, dari sekian banyak sanksi administrasi yang disebutkan, masih belum dilaksanakan dengan maksimal sehingga tidak menimbulkan efek jera bagi para pelanggar alih fungsi lahan. Pemerintah Daerah Kabupaten Kuningan melalui Kantor Satuan Polisi Pamong Praja, melakukan penertiban terhadap para pihak yang diduga melakukan pelanggaran Tata Ruang di kawasan Kecamatan Cilimus, akan tetapi karena sanksi dari penertiban itu hanya bersifat administratif saja, maka penegakan hokum dirasakan masih belum efektif. ${ }^{33}$

\section{Sanksi Perdata}

Penegakan hukum dengan sanksi Perdata diatur dalam pasal 66 dan 67 Undang Undang Penataan Ruang dan Pasal 111 Peraturan Daerah Tentang Rencana Tata Ruang Kabupaten Kuningan 2011-2031. Pasal 66 Undang Undang Penataan Ruang berbunyi :

33 Kesimpulan dari hasil wawancara Pribadi dengan Kepala Satpol PP kabupaten Kuningan, pada tanggal 18 Juni 2015. 
(1) Masyarakat yang dirugikan akibat penyelenggaraan penataan ruang dapat mengajukan gugatan melalui pengadilan.

(2) Dalam hal masyarakat mengajukan gugatan sebagaimana dimaksud dalam ayat (1) tergugat dapat membuktikan bahwa tidak terjadi penyimpangan dalam penyelenggaraan penataan ruang.

Berikutnya dalam Pasal 67 Undang Undang Penataan Ruang menerangkan mengenai penyelesaian sengketa. Sengeketa dapat diselesaikan dengan jalan musyawarah untuk mufakat atau dapat melalui jalur hukum melalui pengadilan sesuai dengan ketentuian yang berlaku. Hal yang sama juga diamanatkan dalam Pasal 111 Pertaturan Daerah Tata Ruang, yang mengatur tentang Hak Masyarakat. Dimana setiap orang berhak untuk:

1. Mengetahui rencana tata ruang

2. Menikmati pertambahan nilai ruang sebagai akibat penataan ruang

3. Memperoleh penggantian yang layak atas kerugian yang timbul akibat pelaksanaan kegiatan pembangunan yang sesuai dengan rencana tata ruang

4. Mengajukan keberatan kepada pejabat yang berwenang terhadap pembangunan yang tidak sesuai dengan rencana tata ruang di wilayahnya

5. Mengajukan tuntutan pembatalan ijin dan ;penghentian pemabngunan yang tidak sesuai dengan rencana tata ruang kepada pejabat yang berwenang, dan

6. Mengajukan gugatan ganti kerugian kepada pemerintah dan atau pemegang ijin apabila kegiatan pemabngunan yang tidak sesuai dengan rencana tata ruang menimbulkan kerugian.

Sarana hukum perdata diajukan apabila masyarakat atau pihak yang merasa dirugikan dalam pelanggaran alih fungsi lahan berupaya melakukan gugatan ke pengadilan. Namun hasil pengamatan di wilayah studi, belum ada kasus sengketa atau gugatan perdata berkaitan dengan tata ruang yang dibawa ke Pengadilan Negeri Kuningan. Setiap 
ada permasalahan tata ruang selalu diupayakan untuk didamaikan berdasarkan musyawarah dan mufakat. Hal ini menandakan bahwa masyarakat Kabupaten Kuningan belum sepenuhnya mempercayai proses peradilan untuk menyelesaikan permasalahan, disamping juga rasa apatis yang tinggi dari masyarakat yang tidak mau berurusan dengan masalah hukum di Pengadilan.

Hal ini sesuai dengan pandangan Eman Suparman, ${ }^{34}$ bahwa Pengadilan dianggap tidak professional untuk menangani kasus persengketaan, tidak independen, bahkan para hakimnya telah kehilangan integritas moral dalam menjalankan profesinya. Akibatnya lembaga Pengadilan yag secara konkret mengemban tugas untuk menegakan hokum dan keadilan ketika menerima, memeriksa, mengadili, serta menyelesaikan sengketa yang diajukan, dianggap sebagai tempat menyelesaikan sengketa yang tidak efektif dan efisien.

\section{Sanksi Pidana}

Ketentuan pidana tidak diatur secara jelas dalam Peraturan Daerah Nomor 26 Tahun 2011, sehingga pelanggaran yang bersifat pidana dikenakan aturan Undang Undang Nomor 26 Tahun 2007 tentang Penataan Ruang. Bagi orang yang melanggar tata ruang yang telah ditetapkan maka sanksi dijelaskan menurut Pasal 69 ayat (1) Undang Undang Nomor 26 Tahun 2007 tentang Penataan Ruang, yang berbunyi :

(1) Setiap orang yang tidak mentaati rencana tata ruang yang telah ditetapkan sebagaimana dimaksud dalam Pasal 61 huruf a yang mengakibatkan perubahan fungsi ruang dipidana dengann pidana penjara paling lama 3 (tiga) tahun dan denda paling banyak Rp 500.000.000,00 (lima ratus juta rupiah)

(2) Jika tindak pidana sebagaimana dimaksud pada ayat (1) mengakibatkan kerugian terhadap harta benda atau kerusakan barang, pelaku dipidana dengan pidana penjara

34 Eman Suparman, Arbitrase dan Dilema Penegakan Keadilan,(Jakarta, PT Fikahati Aneska, 2013) hlm 2-3. 
paling lama 8 (delapan) tahun dan denda paling banyak Rp 1.500.000.000,00 (satu miliar lima ratus jura rupiah).

(3) Jika tindak pidana sebagaimana dimaksud pada ayat (1) mengakibatkan kematian orang, pelaku dipidana dengan pidana penjara paling lama 15 (lima belas) tahun dan denda paling banyak Rp 5.000.000.000,00 (lima miliar rupiah)

Untuk pejabat yang berwenang terbukti menyalahgunakan wewenangnya dengan melanggar tata ruang yang ada, maka dikenai sanksi menurut Pasal 73 Undang Undang tersebut, yaitu :

(1) Setiap pejabat pemerintah yang berwenang yang menerbitkan ijin tidak sesuai dengan rencana tata ruang sebagaimana dimaksud dalam Pasal 37 ayat (7), dipidana dengan pidana penjara paling lama 5 (lima) tahun dan denda paling banyak Rp 500.000.000,00 (lima ratus juta rupiah).

(2) Selain saksi pidana sebagaimana dimaksud pada ayat (1) pelaku dapat dikenai pidana tambahan berupa pemberhentian secara tidak dengan hormat dari jabatannya.

Sarana hukum pidana ditujukan kepada dua pihak, yaitu orang yang mengajukan permohonan dan pejabat yang berwenang. Namun hasil temuan di wilayah studi mendeskripsikan bahwa pada tataran implementasi Undang Undang Nomor 26 Tahun 2007 tentang Penataan Ruang dan Peraturan Daerah Nomor 26 Tahun 2011 tentang Rencana Tata Ruang Wilayah Kabupaten Kuningan 2011-2031 penerapan sanksi Pidana seolah-olah hanya formalitas saja jika ditinjau dari segi penegakan hukumnya, karena pelanggaran alih fungsi lahan masih terus terjadi. Tidak ada upaya yang sungguh-sungguh dari pejabat yang berwenang, karena faktanya tidak ada upaya penegakan hukum bagi seseorang atau perusahaan yang melanggar alih fungsi peruntukan 
maupun bagi pejabat yang berwenang yang memberikan ijin pemanfaatan tata ruang yang tidak sesuai dengan peruntukannya. ${ }^{35}$ Lemahnya penegakan hukum tersebut menurut SoerjonoSoekanto, karena pengaruh hukum tidak hanya terbatas pada timbulnya ketaatan atau kepatuhan pada hukum, namun mencakup efek total dari hukum terhadap sikap tindak atau perilaku baik yang positif maupun yang negatif. Perilaku hukum dapat digunakan sebagai indikator terhadap masalah kesadaran hukum masyarakat sebagaimana yang tercantum dalam indikator pola-pola perikelakukan hukum (legal behavior), sebab adakalanya suatu ketentuan hukum sebagian besar dipatuhi dan ada pula yang tidak sepenuhnya dipatuhi. Akibatnya, bagaimana perilaku hukum dalam masyarakat pada kondisi dengan derajat kepatuhan yang berbeda-beda dalam hal ini berkaitan dengan tingkat kesadaran hukum anggota masyarakat yang bersangkutan, sehingga pada dasarnya antara kesadaran hukum dan kepatuhan hukum jelas saling berhubungan. ${ }^{36}$

Dengan demikian maka prosedur pemanfaatan tata ruang serta sanksi Pidana yang diancamkan belum diterapkan secara optimal di Kabupaten Kuningan. Karena pelanggaran alih fungsi lahan sesuai peruntukan masih terjadi. Keberadaan Badan Koordinasi Penataan Ruang Daerah (BKPRD) sebagaimana diatur dalam Peraturan Menteri Dalam Negeri Nomor 50 Tahun 2009 tentang Pedoman Koordinasi Penataan Ruang Daerah belum berjalan sebagaimana diharapkan. ${ }^{37}$ Padahal Badan yang bersifat adhoc tersebut dibentuk untuk mendukung pelaksanaan Undang Undang Nomor 26 tahun 2007 tentang Penataan Tata Ruang, dan mempunyai fungsi membantu pelaksanaan tugas Bupati dalam koordinasi penataan ruang di daerah. BKPRD adalah suatu bentuk tim koordinasi bidang penataan ruang dalam rangka

Simpulan dari wawancara pribadi dengan Sudarna (63 tahun) Tokoh masyarakat Kecamatan Cilimus.

36 Soerjono Sekanto, Op. Cit, hlm 59.

37 Simpulan dari hasil wawancara dengan Kepala Dinas Tata Ruang dan Cipta Karya Kabupaten Kuningan, pada tanggal 20 Juli 2015. 
menjamin tercapainya tujuan koordinasi penataan ruang yang efektif dan meningkatkan peran Pemerintah dalam pengendalian tata ruang.

\section{E. Penutup}

\section{a. Kesimpulan}

Berdasarkan hasil kajian yang telah dibahas dalam bab-bab terdahulu, maka disimpulkan bahwa:

1. Penetapan Kecamatan Cilimus sebagai salah satu Pusat Kegiatan Lokal di Kabupaten Kuningan berdasarkan Peraturan Daerah Kabupataen Kuningan Nomor 11 Tahun 2011tentang Rencana Tata Ruang Wilayah Kabupaten Kuningan Tahun 2011-2031, telah ditindak lanjuti dengan dibuatnya Rencana Detail Tata Ruang (RDTR) Cilimus. Dalam RDTR, Kecamatan Cilimus dibagi menjadi empat pengembangan kawasan, yaitu kawasan utara untuk pengembangan pemukiman dan perumahan, kawasan kota untuk pusat bisnis dan perkantoran pemerintahan, kawasan tengan untuk pengembangan pariwisata dan kawasan selatan untuk pengembangan lahan pertanian dan pembangunan yang mendukung pariwisata.

2. Terjadi inkonsistensi kebijakan penggunaan lahan pertanian menjadi perumahan. Hal ini diakibatkan karena minimnya kesadaran masyarakat dalam menjaga lingkungan, rendahnya kesadaran hukum aparatur penyelenggara kebijakan, dan upaya pemerintah daerah untuk terus meningkatakan PAD tanpa melihat rencana tata ruang yang telah ditetapkan. Implikasi dari inkonsistensi kebijakan ini memiliki konsekuensi yuridis baik secara administrasi, pidana maupun perdata, sebagaimana telah diatur dalam Undang Undang Nomor 26 Tahun 2007 tentang Penataan Ruang maupun dalam Peraturan Daerah Nomor 26 Tahun 2011 tentang Rencana Tata Ruang Wilayah Kabupaten Kuningan 2011-2031. Namun upaya penegakan hukum terhadap pelanggaran tata ruang ini belum dilakukan secara optimal. 


\section{b. Saran}

Lemahnya koordinasi antar Satuan Kerja Perangkat Daerah (SKPD) di Kabupaten Kuningan dapat dihindari dengan peningkatan kapasitas aparatur Pemerintah guna menunjang pelaksanaan kebijakan di bidang penataan tata ruang, hal ini dapat dilaksanakan dengan mengikutsertakan aparatur dalam bimbingan teknis dan pelatihanpelatihan di bidang penataan tata ruang.

\section{Daftar Pustaka}

\section{A. Buku:}

Agus Salim, 2006, Teori Dan Paradigma Penelitian Sosial (Buku Sumber Untuk Penelitian Kualitatif), Tiara Wacana, Jakarta

Eman Suparman, 2013, Arbitrase Dan Dilema Penegakan Keadilan, PT Fikahati Aneska, Jakarta 
Endang Sutrisno, 2013, Rekontruksi Budaya Hukum Masyarakat Nelayan Untuk Membangun Kesejahteraan Nelayan, Genta Press, Yogyakarta

Esmi Warassih, 2005, Pranata Hukum Sebuah Telaah Sosiologis, Badan Penerbit Universitas Diponegoro, Semarang

F Budi Hardiman, 2003, Melampaui Positivisme dan Modernitas(Diskursus Filosofis tentang Metode IImiah dan Problem Modernitas, Pustaka Fislafat, Yogyakarta

Faisal Sanafiah, 1990, Penelitian Kualitatif Dasar-Dasar dan Aplikasi, Penerbit Ya.3, Malang

Hadi Sabari Yunus, 2008, Struktur Tata Ruang Kota, Pustaka Pelajar, Jogjakarta

Hilman Hadikusuma, 1986, Antropologi Hukum Indonesia, Penerbit Alumni, Bandung.

I Gde Pantja Astawa, 2013, Problematika Hukum Otonomi Daerah di Indonesia, PT Alumni, Bandung

Irfan Islamy, 2001, Prinsip-Prinsip Kebijakan Negara, Bumi Aksara, Jakarta

Marc Galenter, 1993, Modernisasi Sistem Hukum Dalam Myron Weiner(ed), Modernisasi Dinamika Pertumbuhan cet.III, Gajah Mada University Press, Yogyakarta

M Daud Silalahi, 2001, Hukum Lingkungan Dalam Sistem Penegakan Hukum Lingkungan di Indonesia, Alumni, Bandung Mochtar Kusuma Atmadja, 1996, Fungsi dan Perkembangan Hukum Dalam Pembangunan nasional, Penerbit Bina Cipta, Bandung

Munir Fuady, 2007, Dinamika Teori Hukum, Ghalia Indonesia, Bogor Otje Salman dan Anthon F Susanto, 2010, Teori Hukum, Refika Aditama, Bandung

Riant Nugroho, 2014, Public Policy: Teori, manajemen, Dinamika, Analisis, Konvergensi, dan Kimia Kebijakan,PT Elex Media Komputindo, jakarta

Ronny Hanityo Soemitro, 1990, Metode Penelitian Hukum dan Jurimetri, Galia Indonesia, Jakarta

Samsul Arifin, 2004, Upaya Penegakan Hukum Dalam Mewujudkan Pembangunan, Pustaka Bangsa, Medan Satjipto Rahardjo, 2012, Ilmu Hukum, Citra Aditya Bakti, Bandung 
Salim HS dan Erlies Septiana Nurbaeti, 2013, Penerapan Teori Hukum Pada Penelitian Tesis Dan Disertasi, PT Grafindo Persada, Jakarta Sidharta, 2006, Moralitas Profesi Hukum Suatu Tawaran Kerangka Berpikir, Refika Aditama, Bandung

Soerjono Soekanto, 1988, Efektivikasi Hukum Dan Peranan Sanksi, Remaja Karya CV, Bandung

Rajawali CV, Jakarta

Sudarwan Danim, 2002, Menjadi Peneliti Kualitatif, Pustaka Setia, Bandung

Sutandyo Wignyo Subroto, 2002, Hukum Paradigma, Metode dan Dinamika, Elsam, Jakarta

Sunarjati Hartono CFG, 1985, Hukum Ekonomi Pembangunan Indonesia, Penerbit Binacipta, Bandung

Wayne Parsons, 2008, Public Policy:Pengantar Teori dan Praktek Analisis Kebijakan( dialihbahasakan oleh Tri Wibowo Budi Santoso), PT Kencana, Jakarta

\section{B. Peraturan Perundang-undangan:}

Undang Undang Nomor 26 Tahun 2007 tentang Penataan Ruang.

Peraturan Daerah Nomor 12 Tahun 2007 tentang Konservasi Sumber Daya Air.

Peraturan Daerah Nomor 11 Tahun 2013 tentang Hutan Kota. 